\title{
Gastric Neuroendocrine Tumor Clinical Distant Metastasis TNM Finding v8
}

National Cancer Institute

\section{Source}

National Cancer Institute. Gastric Neuroendocrine Tumor Clinical Distant Metastasis

TNM Finding v8. NCI Thesaurus. Code C135022.

A clinical finding about one or more characteristics of a gastric neuroendocrine tumor, following the rules of the TNM AJCC v8 classification system as they pertain to distant metastases. 